\title{
Interação Estratégica e Concursos Públicos: Uma Etnografia do Concurso da Magistratura Francesa
}

\section{Fernando de Castro Fontainha}

Instituto de Estudos Sociais e Políticos (IESP) da Universidade do Estado do Rio de Janeiro (UERJ), Rio de Janeiro, RJ, Brasil. E-mail: fernando.fontainha@iesp.uerj.br

- Isto para um concurso é... é terrível de dizer porque... é estratégia do início ao fim...

- É! Estratégia!

- Tem que ser esperto, mais que inteligente...

- Mas é verdade...

- E é uma pena!

- É um jogo de antecipação, eles sabem o que eles querem e como eles querem. (Diálogo entre duas jovens magistradas francesas em um de meus grupos focais realizados na École Nationale de la Magistrature, em 2008).

\section{INTRODUÇÃO}

ada vez mais no Brasil, e particularmente entre os jovens juristas, a opção pelos concursos públicos como pilar de inserção profissional vem ganhando vulto. Como via de acesso quase exclusiva às carreiras de Estado, e notadamente às carreiras jurídicas, a preparação e a passagem por concursos públicos é etapa obrigatória e decisiva da vida profissional de um número crescente de diplomados em Direito.

No entanto, o concurso público é raramente apreendido como um objeto pela sociologia das profissões jurídicas, que ainda se fia às duas abordagens clássicas, quais sejam: (1) o aprendizado profissional nas DADOS - Revista de Ciências Sociais, Rio de Janeiro, vol. 58, n-2, 2015, pp. 1057 a 1098. 
faculdades de Direito; e (2) a formação profissional e a dinâmica das carreiras jurídicas em si. Localizado entre estes dois momentos da trajetória profissional de muitos juristas está o período compreendido entre sua formatura e sua posse em um cargo público.

Já repertoriei as publicações sobre este tema na literatura francófona sobre a magistratura (Fontainha, 2014), e constatei que existe um verdadeiro "ponto cego" no tocante ao recrutamento dos juízes, ressalvada a pesquisa de Fillon, Bonichi e Lecompte (2008), bem como as teses de doutorado de Oger (2002) e Billand (2008). Muito se produz sobre o ensino do Direito, sobre a Escola Nacional da Magistratura e sobre o trabalho em jurisdição, sem, entretanto, quase nenhuma dedicação a este momento crucial da vida profissional. Apostando justamente no poder de explicação que o aprofundamento do discurso científico sobre os concursos públicos pode trazer à sociologia das profissões jurídicas, este artigo pretende consolidar e propor um quadro de análise baseado em uma Teoria dos Jogos, tal como a organizada por Erving Goffman.

É fora da sociologia das profissões e da sociologia do Direito que se encontra o debate sobre processos de seleção social, em particular das seleções segundo métodos e critérios escolares (dinâmicas nas quais a performance dos selecionados é avaliada por meio de provas escritas e/ou orais por selecionadores). Este debate, objeto da sociologia da Educação (Van Haecht, 2006; Duret, 2009), tem sido organizado em torno de dois referenciais: o determinista, paradigma dominante, e o construtivista. A visão determinista, projeto ambicioso e complexo, é baseada numa sociologia holística, em que a excelência individual é emissária da dominação e o fracasso é produto de injustiças. A reprodução como teoria do sistema de ensino e de seleção social foi elaborada por Bourdieu e Passeron, inicialmente no livro Les Héritiers (1964), e posteriormente em La Réprodution (1970), e é em realidade um olhar sobre a escola na sociedade de classes bem mais desenvolvido que o dos marxistas.

Este artigo buscará propor um quadro analítico para os concursos públicos a partir da segunda tradição deste debate, motivo pelo qual não se estenderá acerca da teoria da reprodução. Num primeiro momento, ele mostrará como o construtivismo avançou em direção à compreensão dos processos de competição de atores, notadamente as competições escolares. Em seguida, analisará a recepção da Teoria dos Jogos 
pela sociologia, após ter nascido na Matemática e conhecido grande uso na Economia. Finalmente, ele construirá progressivamente o olhar goffmaniano sobre as dinâmicas interacionais, começando pelas interações cotidianas (metáfora do teatro), passando pelas interações focalizadas e desembocando nas interações estratégicas (metáfora do jogo). Por fim, será trazida uma etnografia da prova oral de cultura geral da magistratura francesa, em que as categorias teóricas trabalhadas poderão ser aplicadas através da descrição densa de quadros interacionais.

\section{A EMERGÊNCIA DA COMPETIÇÃO DE ATORES NO CONSTRUTIVISMO}

Desde os anos 1980, os sociólogos franceses vêm sendo tocados por dois movimentos simultâneos: o abandono do marxismo e a adesão à sociologia interacionista americana, notadamente a produzida pela segunda geração da Escola de Chicago, formada por Herbert Blumer e Everett Hughes e conhecida por suas críticas ao determinismo e ao funcionalismo. O retorno do ator e a perspectiva atomista ganham lugar na sociologia francesa, o pluralismo interpretativo avança de encontro às teorias holísticas e a dimensão empírica ganha importância considerável. Florent Champy explica esta conversão na sociologia das profissões ${ }^{1}$ :

Em primeiro lugar, o desgaste do paradigma marxista obrigou certos pesquisadores a encontrar novas orientações de pesquisa. Além disso, o recuo da influência e do crédito do marxismo, por muito tempo importante na sociologia francesa, se fez acompanhar de uma desconfiança em relação às "grandes teorias", tornando muito atrativa a empiria e a descrição da diversidade de situações, que é constitutiva [...] do interacionismo. [...] Por fim, a sociologia interacionista comporta um último atrativo para os sociólogos que, ainda que não venham do marxismo, são majoritariamente de esquerda: sua dimensão crítica (2009:29).

O importante aqui é a compreensão de como os autores desta sociologia crítica - da qual o interacionismo simbólico é a fonte - podem contribuir para a compreensão de processos como os concursos públicos.

A primeira geração da Escola de Chicago ${ }^{2}$, impulsionada por diversos fatores, foi, após a escola parisiense de Émile Durkheim, a maior referência na produção sociológica no século passado. No entanto, a maior contribuição da Escola de Chicago para a sociologia é talvez a relação que sua produção guarda com a pesquisa de campo, o que transformou 
profundamente a relação entre o pesquisador e seu "objeto". Considerada a primeira grande obra produzida por aquela geração, The Polish Peasant in Europe and America de Thomas e Znaniecki (1920), já trazia uma longa nota metodológica (120 páginas) e uma concepção avançada sobre dados primários (first-hand data). Segundo os autores:

Temos que nos colocar na posição do sujeito que tenta achar seu caminho no mundo, e temos que lembrar, em primeiro lugar, que o ambiente que o influencia e ao qual ele se adapta é o seu mundo, e não o mundo objetivo da ciência - é a natureza e a sociedade assim como ele as vê, não como os cientistas as veem (ibidem, vol. 2:1846-1847).

O indivíduo aparece então como fonte de conhecimento sociológico, não mais como objeto de forças e determinações sociais. Estudar o comportamento dos indivíduos em comunidade é tornar visível a sociedade tal como ela é vivida pelos seus membros.

Outra enorme contribuição, oriunda da relação entre a cidade de Chicago e sua Universidade, é a noção de "laboratório" em sociologia, que, segundo Burgess, era a própria cidade (1929:47). Testemunha de um enorme crescimento entre 1840 e 1940 e de uma explosão de diversidade, a cidade de Chicago torna-se um laboratório de sociologia. Uma parte desta tendência empírica é devida a Park, que graças à sua experiência anterior como jornalista, cria na proximidade física entre o sociólogo e seu objeto de estudo um imperativo de trabalho.

No livro que ambos, Park e Burgess, escreveram, Introduction to the Science of Sociology, conhecido nos Estados Unidos como green bible, eles expõem sua concepção sobre o lugar da empiria no conjunto da produção científica:

Fatos não foram coletados para verificar as teorias sociais. Os problemas sociais foram definidos em termos do senso comum, e os fatos foram recolhidos, na maioria das vezes, para apoiar esta ou aquela doutrina, não para testá-la. Em muito poucos casos pesquisas foram feitas desinteressadamente, para determinar a validade de uma hipótese (1921:44).

Esta geração substitui o primado da teoria pelo da empiria, fazendo nascer a sociologia conhecida como interacionismo simbólico. Ela reivindicava seu caráter crítico pela oposição ao determinismo e ao funcionalismo, podendo ser explicada a partir de quatro conceitos centrais: 
Estes quatro conceitos centrais são: (1) as pessoas, individual e coletivamente, estão preparadas para agir em função dos significados dos objetos que compõem o seu mundo, (2) a associação de pessoas está disposta, necessariamente, na forma de um processo no qual elas fazem indicações umas às outras, interpretando as indicações uns dos outros, (3) atos sociais, individuais ou coletivos, são construídos através de um processo em que a observação dos atores interpreta e avalia as situações confrontando-as, e (4) a complexa interligação dos atos que compõem a organização, as instituições, a divisão do trabalho e as redes de interdependência, se move e não implica temas estáticos (Blumer, 1969:50).

Esta corrente pode ser qualificada de radical na medida em que reconhece não apenas a autonomia de ação do indivíduo, mas igualmente sua criatividade, visto que as funções, os sentidos e os objetivos das múltiplas ações mudam no curso das interações e são permanente e reflexivamente renegociados ao longo do tempo. Poder-se-ia dizer se tratar de uma teoria ancorada no mundo empírico, primeiro porque se trata de um produto de pesquisas efetuadas; segundo, porque apenas sua completude por dados primários lhe acorda sentido.

Goffman foi um autor que decidiu levar a interação face a face ao estatuto de categoria fundamental da Sociologia. Seu trabalho mais conhecido, The Presentation of Self in Everyday Life, utiliza a metáfora de uma representação teatral para explicar o comportamento social quotidiano, e a maneira como as pessoas interagem umas com as outras. Em Goffman o ser não é importante, pois o jogo de expressões é tão complexo que o que compartilhamos justamente são as técnicas de controle e veiculação de informações pessoais e sociais. Nas palavras do autor:

Um personagem encenado em um teatro não é algo de real, nem obedece ao mesmo tipo de consequências reais como faz o personagem completamente artificial encenado por um homem de confiança, porém a encenação bem-sucedida de ambos estes falsos personagens envolve o uso de técnicas reais - as mesmas técnicas pelas quais pessoas comuns sustentam suas situações sociais reais (Goffman, 1959:255).

É importante perceber que no vocabulário de Goffman não há apenas o ator (actor), mas também o receptor (recipient), numa dialética em que cada participante da interação é ator e receptor a seu turno, e na qual as trocas informacionais podem se tornar densas. O processo cognitivo que subjaz a esta dinâmica é o de avaliação das expectativas normati- 
vas do outro e de realização prática de obrigações, construindo um rito interacional comportando fluxos de golpes e contragolpes bastante complexos. Partindo daqui, uma sociologia do aprendizado aplicada à competição objetiva pode se desenvolver.

Para Goffman, a ação individual e a apresentação de si ganham uma dimensão estratégica. Para ilustrar este propósito, evocarei a noção de mobilidade social como questão maior acerca da competição escolar. $\mathrm{O}$ sucesso num concurso ou numa prova não é necessariamente uma vitória; ela pode ser, ao contrário, um sinal de derrota (Goffman, 1952:463). No olhar goffmaniano, portanto, tornar-se um magistrado ou um promotor de justiça não é necessariamente uma vitória pessoal ou social, uma vez que a conquista desta posição deve ser relativizada pela posição já ocupada e/ou almejada por cada um. Assim, as motivações e os sentimentos pessoais contam unicamente na medida em que são objetivados sob a forma de estratégias e técnicas de gerenciamento de informações pessoais e sociais. Por exemplo, um candidato que tenta encobrir ou fazer passar despercebido um traço desviante seu (um estigma) aos olhos da banca avaliadora (Goffman, 1963:130). A primeira questão levantada por esta corrente que toca os concursos é o comportamento desviante. Considerando que vivemos num emaranhado de normas sociais - certo, que retocamos e renegociamos a cada momento -, o comportamento desviante traz a questão da simetria entre indivíduos e grupos sociais. O universo dos candidatos não é o mesmo dos membros da banca examinadora, e estes dois grupos não possuem igualdade de condições na produção das regras da competição, como afirma Becker no seu livro consagrado aos outsiders: "As diferenças na capacidade de criar regras e aplicá-las a outras pessoas são, essencialmente, os diferenciais de poder (legal ou extralegal). Esses grupos, cuja posição social lhes dá armas e poder, são mais capazes de impor as suas regras" (ibidem:18).

Para avançar sobre o tema, passarei à contribuição de Garfinkel, fundador da etnometodologia, que mesmo sem pertencer à Escola de Chicago, com ela partilha muitos referenciais teóricos e metodológicos. No seu vocabulário, os atores tornam-se membros, na medida em que partilham os mesmos conhecimentos e as mesmas práticas quando de um determinado contexto. Assim, a normatividade dá espaço à interpretação e três conceitos analíticos fundamentais aparecem: a indexicalidade (ligação entre uma forma linguística e um contexto), a reflexividade (dialética entre descrever e constituir uma situação) e a 
descritibilidade (pensar o mundo como observável e descritível). Para Garfinkel, os principais imperativos da pesquisa empírica são a observação direta, a descrição densa e a imersão duradoura do pesquisador nos contextos sociais rotineiros (vendo os fatos sociais como realizações práticas). Do lado do account, um dos conceitos fundamentais da etnometodologia é a Sociologia leiga (lay Sociology), que o autor opõe à sociologia profissional (Garfinkel, 1967:75).

Assim, é reconhecida aos indivíduos, além da autonomia e da criatividade, a capacidade de elaboração sociológica, em que a relação de cada um com os diferentes grupos produz fortes referências cognitivas e o senso comum cresce em importância, tornando-se um critério fundamental de análise da sociedade. Para o autor, então, a figura de um indivíduo marcado pelo desconhecimento sobre as condições de produção de sua vida em coletividade é inexistente: não há um idiota cultural (judgemental dope).

Coulon e Dupret, dois etnometodólogos franceses, utilizam esta noção como ponto forte da difusão do pensamento de Garfinkel na França (Coulon, 1993:648; Dupret, 2001:441). Esta tradição elegeu a educação como um dos seus temas centrais, também orientada pela crítica ao determinismo e ao funcionalismo, que se manifestavam na França através da teoria da reprodução, mas que nos Estados Unidos se tratava de uma corrente otimista (a escola como lugar da pura seleção meritocrática). Um dos primeiros trabalhos que marcam esta crítica é The Educational Decision-Makers, de Cicourel e Kitsuse (1963), no qual são relativizadas categorias comumente utilizadas para explicar a seleção escolar, como o mérito, o dom, a vocação e a competência técnica e científica (Filloux, 1994).

A rejeição dos atributos românticos da Escola não concilia deterministas e interacionistas, ao contrário. Mehan, em seu artigo intitulado "Structuring School Structure" se opõe claramente à noção de estrutura em prol da de atividades estruturantes: a seleção não é determinada por critérios (pré)estabelecidos, mas através (e ao curso) da interação dos professores e alunos (Mehan, 1978:36 apud Coulon, 1994:69).

Esta abordagem mostra outra distinção entre o determinismo e o interacionismo acerca da noção de competência. Baseada na dimensão relacional, a competência social é a capacidade de mobilização de um capital (cultural, social, econômico, jurídico ou simbólico) na perseguição de um objetivo. Porém, se o referencial se desloca em direção às intera- 
ções, a competência se torna estratégica e incorpora um fator cognitivo (social, não psicológico): a realização prática, como afirma Mehan no seu artigo "The Competent Student":

Esmiuçando esses pontos de vista, obtém-se uma concepção de competência como sendo as ferramentas exigidas, habilidades, e conhecimentos necessários para uma participação em uma determinada comunidade. [...] A competência para a participação na interação não é uma consideração subjetivista. É uma consideração social. A competência interacional não está a ser equacionada com habilidades subjacentes ou reduzida ao nível de uma pessoa individual. [...] As pessoas têm de mostrar o que sabem. [...] A competência, então, é congregada por pessoas que se relacionam umas com as outras. (1979:3-4)

Garfinkel já afirmou, de forma jocosa, que não se deve procurar respostas na cabeça das pessoas, pois lá só há massa cinzenta (1963). A competência não é o produto de uma acumulação de conhecimentos ou de quaisquer outros atributos meramente intelectuais, é necessária sua realização prática e contextual. Não se trata de pensamento $e$ ação, mas do pensamento em ação (Goffman, 1979). No caso dos concursos públicos, o conhecimento pretensiosamente avaliado seria o conhecimento jurídico, e para tanto contamos com avaliadores profissionais, baremas, provas com programas e gabaritos. No entanto, o domínio da dimensão estratégica tácita - esta que tentaremos demonstrar como determinante na competição - das regras dos concursos é ao menos tão importante quanto conhecer as leis, doutrinas e tendências jurisprudenciais (ibidem:27).

É necessário sublinhar que a dimensão tácita não evoca o referencial do falso conhecimento ou da ignorância (méconnaissance). Sua dimensão interacional é conhecida de todos, podendo até mesmo - e no caso dos concursos públicos para as carreiras jurídicas no Brasil minha hipótese é que o são - ser objeto de elaborações estratégicas finas, por vezes mesmo conferindo o sentido prático do processo de seleção. Ela é tácita na medida em que não é objetivada de início (tomada como fato objetivo), pelos programas das disciplinas, gabaritos e baremas, tampouco utilizada para justificar uma resposta (pelos candidatos) ou ainda para legitimar uma nota atribuída (pelos avaliadores). Esta problemática é o cerne da crítica de Mehan ao sistema de ensino americano (Coulon, 1994:87).

Berger e Luckmann (1996:18), contribuem para este debate na medida em que unificam teoricamente a objetividade de Durkheim e a subjeti- 
vidade de Weber, explicando que a realidade social é construída a partir da interpenetração entre uma facticidade objetiva e um sentido subjetivo. Este movimento, dentro do qual o sentido subjetivo se torna uma facticidade objetiva, segundo os autores, possui três tempos dialéticos: a exteriorização (a projeção humana no mundo), a objetivação (os produtos da projeção retornam aos seus criadores como dados externos) e a interiorização (a reapropriação destas realidades exteriores). Assim, a descontinuidade e a produção e reprodução dinâmica da simetria entre subjetividade e objetividade fazem aparecer a questão da distribuição social do conhecimento (ibidem:46).

Ao que toca o propósito deste artigo, a noção de distribuição e uso dos recursos cognitivos os converte em verdadeiras ferramentas cognitivas (Van Haecht, 2006). De uma forma geral, busquei na sociologia interacionista a ideia fundamental de explorar nos processos de objetivação a fonte para compreender a dinâmica de seleção nos concursos públicos, ficando claro que estes processos se dão em paralelo às regras oficiais e explícitas dos concursos. De início, a seleção deve ser encarada como produto da interação de candidatos com uma banca. A proposta é a investigação dos processos pelos quais os candidatos apreendem as fórmulas que consideram potencializadoras de suas chances de sucesso, para elaborar, testar e aprimorar uma prestação quando das provas (processos de elaboração estratégica). Igualmente, a atuação da banca deve ser vista como a realização de um trabalho prático, no qual a avaliação dos candidatos é feita de maneira desestruturada, mas consciente, e é centrada no exame de pertinência e competência dos processos de objetivação (estratégias) realizados por eles. Passamos agora à construção da noção de jogo.

\section{GOFFMAN E A METÁFORA DO TEATRO}

Aquilo que conhecemos hoje como Teoria dos Jogos não passa da denominação generalista de uma corrente, originária de certos matemáticos, que ao longo do século passado cresceu incrivelmente, tanto em número de usuários quanto através das áreas do conhecimento ${ }^{3}$. Sem a ambição de restituir a integridade de sua criação e desenvolvimento, é necessário ao menos dizer que neste artigo, quando falo de Teoria dos Jogos, me refiro a um uso particular que dela fazem alguns autores, sobretudo Goffman.

É nos anos 1950 que a Teoria dos Jogos chega na sociologia, com a publicação do artigo de Jessie Bernard, "The Theory of Games of Strategy 
as a Modern Sociology of Conflict" no American Journal of Sociology, em 1954, e a publicação de Games and Decisions, de Robert Luce e Howard Raiffa, em 1957, sob a direção de Lazarsfeld. Um balanço do uso sociológico da Teoria dos Jogos entre 1950 e 2000 foi feito por Swedberg (2001:309), que classifica seis diferentes abordagens, comparando-as e identificando suas principais temáticas. Uma destas seis abordagens a que concerne este trabalho - consiste na utilização dos jogos como uma metáfora, em que o vocabulário da Teoria dos Jogos (jogo, jogador, estratégia...) é empregado de maneira não técnica por autores como Elias, Crozier, Thoenig, Burawoy, e também Goffman. Este último o faz no intuito de melhor compreender as interações estratégicas.

Muito mais conhecido pelas suas pesquisas e seus conceitos em torno de outra fonte metafórica - o teatro -, Goffman consagrou a maior parte dos seus trabalhos ao comportamento quotidiano das pessoas em coletividade. É em torno da noção de realidade social como dramatização que ele constrói o fundamento de seu interacionismo. No entanto, quatro de seus trabalhos ${ }^{4}$ foram dedicados à compreensão de um outro tipo de situações sociais: aquelas nas quais o risco e a consequencialidade estão fortemente presentes. Assim, para construir o quadro compreensivo com o qual pretendo analisar situações como a seleção por concursos públicos, é necessário acompanhar Goffman progressivamente, de início através das interações quotidianas, passando pelas interações focalizadas, para, enfim, chegarmos às interações estratégicas.

Quando fala de seu quadro analítico, Goffman faz mais que justificar a adoção de uma fonte lexical de denominação. Ele compara o mundo social a um palco, afirmando o caráter performativo da vida cotidiana, em que as pessoas encontram os mesmos problemas que os atores quando estão em cena (1974:124-155). A apresentação de si na vida cotidiana é o tema que nos permite resumir grosseiramente a obra deste autor. A compreensão da realidade social como fruto de um processo no qual somos ato e receptor ao mesmo tempo (e ao curso das interações) implica, de um lado, um movimento cognitivo de apreensão informacional de expectativas, e de outro, o cumprimento prático de obrigações.

Não devemos imaginar que por atribuir importância ao aspecto ritual da interação humana o autor nega as relações de poder. Neste tocante, o autor distingue duas classes de regras de conduta: simétricas e assi- 
métricas (Goffman, 1967:52-53). As regras simétricas vinculam os indivíduos partícipes da interação às mesmas expectativas e obrigações, enquanto as assimétricas os vinculam a expectativas e obrigações diferentes. Ele mesmo nos fornece um bom exemplo de objetivação de relação de poder a partir da assimetria observada nas interações de médicos com enfermeiras quando de sua pesquisa realizada num hospital psiquiátrico (Goffman, 1961a). Ele conta que observou os médicos dando ordens e instruções às enfermeiras, mas nunca o contrário; assim como viu comumente enfermeiras se levantando quando da entrada de um médico no cômodo, mas o contrário jamais se deu. Esta noção também nos é bastante útil para entender a relação existente entre os membros da banca avaliadora e os candidatos aos concursos em termos de assimetrias que objetivam relações de poder. Dois propósitos são os pilares do interacionismo goffmaniano.

O primeiro é a noção segundo a qual os laços entre ator e receptor são os laços da sociedade. Ele se inspira na ideia durkheimiana de que a personalidade individual pode ser vista como uma fração do mana coletivo (Durkheim, 1960:343-390), e que os ritos que são realizados para representar a coletividade social podem, por vezes, ser realizados individualmente (Goffman, 1967:47). É isto que permite o enfrentamento dos fenômenos sociais a partir da análise das interações humanas.

O segundo é a noção de que estes laços entre os indivíduos são feitos de normas que os vinculam uns aos outros, regras de conduta que possuem uma dupla força. O caráter direto destas normas tem a força de uma obrigação, estabelecendo de que forma um indivíduo é moralmente obrigado a se comportar em relação aos outros, e o caráter indireto dessas normas possui a força de uma expectativa, estabelecendo como os outros são moralmente obrigados a se comportar em relação a ele (ibidem:49).

Estes dois pressupostos teóricos trazem uma implicação metodológica extremamente importante para este trabalho, baseada numa distinção de inspiração durkheimiana ${ }^{5}$ entre regras substantivas e regras cerimoniais. As regras substantivas são aquelas que instituem expectativas e obrigações acerca de objetos importantes em si, e as regras cerimoniais são aquelas que instituem expectativas e obrigações sentidas como secundárias (ibidem:53-54). Daremos um exemplo que ilustra a distinção, provindo exatamente do tema deste artigo e da minha experiência em campo. Segundo uma norma substantiva, um can- 
didato que se apresenta perante uma banca quando de um exame oral não deve, durante a arguição, evocar suas origens sociais ou mesmo seus laços de parentesco ou relacionais tentando, com isto, se favorecer, e, segundo uma norma cerimonial, ele deve apresentar-se bem trajado, de paletó e gravata. A aparente futilidade da segunda norma esconde o fato de que ela impõe ao candidato referências para a ação e restrições ao quadro interativo tão severas quanto a primeira. Mesmo se a primeira norma descrita serve para proteger a impessoalidade imposta às seleções por concurso público, a segunda não deve ser considerada como menos importante, pois ela tende a proteger igualmente um valor ligado à sacralização do indivíduo: o respeito aos ritos de interação. O candidato também será julgado pela sua capacidade de corresponder de forma pertinente e competente às expectativas que a banca coloca sobre ele e, em o fazendo, dá sentido à seleção, permitindo e instrumentalizando a objetivação do trabalho de seleção.

Entretanto, as implicações metodológicas vão além desta distinção. Uma vez que o autor considera que os laços que unem ator e receptor são os laços da sociedade, e que os ritos coletivos podem ser reproduzidos individualmente, a compreensão da realidade social pode ser feita a partir da análise das relações mais superficiais, rotineiras e cotidianas que cada um mantém com os demais. Em outras palavras, ao tentar explicar o fato social através das interações humanas, é metodologicamente vantajosa a valorização das interações baseadas em normas cerimoniais, gestos e expressões aparentemente vazios, que são, na verdade, repletos de significado e de mais fácil acesso, uma vez que as oportunidades de ver afirmada a ordem moral são relativamente mais raras dado ao operacional necessário à efetivação das normas substantivas. O autor evoca ao menos três razões que justificam essa vantagem metodológica: os ritos baseados em normas cerimoniais são mais breves, eles não têm implicações substantivas, e podem ser repetidos indefinidamente em cada interação (Goffman, 1967:90-95).

Goffman distingue dois elementos fundamentais da atividade cerimonial: a deferência (deference) e a conduta (demeanor). Por deferência (1967:56-77), o autor entende o componente da atividade que é um símbolo que em si confirma a relação do ator com o receptor. Para melhor compreensão deste conceito, Goffman se inspira na distinção que faz Durkheim entre cultos positivos e cultos negativos (Durkheim, 1960:427) para dividir os rituais deferenciais em rituais de apresentação (presentation rituals) e rituais de esquiva (avoidance rituals). Os ri- 
tuais de esquiva (negativos) são todos aqueles que dizem respeito à manutenção da distância, o tabu contra o ato de tocar, a discrição, enfim, a preservação da esfera ideal de que falava Simmel (1950:321).

Exemplos de rituais de esquiva poderiam ser os pequenos gestos e respostas ligeiramente "atravessadas" que podemos dar aos outros quando queremos demonstrar falta de tempo, paciência ou humor, ou quando não temos vontade de interagir. Os rituais de apresentação (positivos) mostram de que maneira o ator vê o receptor e indicam como ele vai tratá-lo ao curso da interação. Exemplos de rituais de apresentação são cumprimentos, convites, elogios, e outros pequenos gestos que exprimem ao menos o desejo e a disposição de manter o rito de interação.

Por sua vez, a conduta é o componente da atividade cerimonial que se manifesta através da maneira de se portar, de se vestir e de postar (Goffman, 1967:77-81). O comportamento é o vetor da boa (ou da má) impressão que alguém pode causar quando na presença imediata de outros. Assim, "se portar bem" é uma questão de exercício do caráter ou da competência que chamamos, por vezes, de "sociabilidade", ou de "socialização". É através do comportamento que cada um cria uma imagem de si. Uma nota interessante a este propósito é referente à ajuda profissional que por vezes é engajada para a potencialização do comportamento: cabeleireiros, conselheiros de moda, enfermeiras que preparam os pacientes e guardas que arrumam os presidiários nos dias de visita... Eu mesmo já tive a oportunidade de constatar que muitos candidatos e dirigentes de institutos de preparação ao concurso da magistratura francesa fazem uso de profissionais de coaching, especializados na assessoria para recrutamentos no setor privado (Fontainha, 2011:283-289). Dito isto, podemos continuar a compor o "palco".

A primeira noção a desenvolver é a de face. Num mundo onde as pessoas vivem múltiplos encontros sociais, a face de alguém apenas pode ser o produto de um complexo arranjo de impressões. Uma face, então, é o conjunto de valores e de atributos sociais valorizantes que reivindicamos efetivamente quando de cada contexto interacional de que fazemos parte. Ou, ainda nas palavras de Goffman:

O termo face pode ser definido como o valor social positivo que uma pessoa reivindica efetivamente para si mesmo por meio da direção que outros assumem que ele tomou durante um contato particular. Face é uma imagem de si delineada em termos de atributos sociais aprovados 
- mesmo que a imagem que os outros possam compartilhar, seja a de uma pessoa que faz uma boa exibição de sua profissão ou religião, tornando uma boa exibição para si mesmo (1967:5).

Assim, dependendo do contexto no qual nos encontramos, dependendo dos interesses que queremos realizar, segundo as vontades e desejos que nos guiam, reivindicamos uma face. E é justamente este processo de formação de um "eu" polivalente na interação que é necessário para distinguir a identidade real da virtual, e a identidade pessoal da social.

A identidade virtual se refere às pressuposições feitas a respeito da "face" de alguém, possuindo potencialmente um caráter retrospectivo, uma vez que existem categorias e atributos que compõem a identidade real, e que podem ser efetivamente apreendidos e verificados (Goffman, 1963:2-3). A dinâmica que se desenvolve quando da presença imediata de ator e receptor é a capacidade do primeiro de construir para si um conjunto informacional e de mostrá-lo, assim como a capacidade do segundo de verificar e de procurar limites e nuances (ou mesmo imposturas) destas informações. Por sua vez, estas fontes informacionais são tanto sociais (um pingente da estrela de Davi significa uma verdadeira pertença à comunidade judaica?) quanto pessoais (uma aliança no dedo significa um verdadeiro casamento?). A dramatização das relações entre os indivíduos começa com a precarização do si, ao menos se considerarmos que o ser em si ou o ser em si mesmo não existem, e em seu lugar temos o ser como objeto permanente de construção e verificação, evidentemente variando em função de cada contexto interacional. É neste ponto que a questão do controle informacional ganha relevo e pertinência. É necessário passar ao último conceito que forma a perspectiva do teatro: as expectativas normativas.

No tocante à questão da identidade e da informação, mesmo quando iniciamos uma interação com uma pessoa que não conhecemos ela não é para nós uma "folha em branco" que será preenchida ao longo deste ritual. Todas as expectativas que um ator porta acerca de um receptor antes de conhecê-lo chamamos expectativas normativas. Na sua dimensão mais larga (aquela que se aproxima do julgamento, positivo ou negativo), as pessoas compartilham um conjunto de expectativas normativas, oriundas do conhecimento adquirido da vida em comunidade.

Evidentemente, um contexto comunitário é ancorado num contexto cognitivo, o que significa que uma mudança de rede interativa implica uma mudança de pertença a uma comunidade de expectativas normati- 
vas. É como transformar o "para tornar-se funcionário público, é necessário conhecer o Direito" em "para se tornar funcionário público, é necessário conhecer a banca examinadora". Ainda que as duas ideias não estejam ancoradas na realidade objetiva, elas se farão reais nas suas consequências, na medida em que servirão de referência para a orientação (ferramenta cognitiva) de ao menos o início de uma interação. Na sua dimensão mais estrita, as expectativas normativas são veiculadas através de marcas de identidade (identity tags), ou "etiquetas" que um ator pode perceber vinculadas ao receptor antes mesmo de conhecê-lo.

A todo momento na vida cotidiana lidamos com questões e dilemas envolvendo dinâmicas interacionais, em que a administração de informações cumpre um papel essencial. É vivendo em permanência estes dilemas e questões que praticamos e aprimoramos nossos meios de sucesso social, que são absolutamente ligados ao ato de interagir, não tendo qualquer relação com o "capital", tampouco com o que quer que seja exterior ou precedente ao dado contexto interacional. É o que chamamos anteriormente "competência interacional" e que Simmel chama de "arte da sociabilidade" (Simmel, 1950:45-46).

A compreensão das categorias utilizadas por Goffman para analisar as interações na vida cotidiana, urbana e secular é absolutamente indispensável caso queiramos nos valer de seu interacionismo como ferramenta explicativa de outros tipos de interação, muito menos rotinizadas, nas quais a arte da sociabilidade dá lugar a uma verdadeira competência estratégica.

\section{DAS INTERAÇÕES COTIDIANAS ÀS INTERAÇÕES FOCALIZADAS}

Até aqui tratamos dos termos gerais e básicos do interacionismo de Goffman voltado à compreensão da vida cotidiana. O autor centra sua abordagem em situações que poderíamos qualificar de pouco institucionalizadas do ponto de vista cerimonial. Quando da presença imediata de outros, basta que cada um de nós recorra minimamente às suas expectativas normativas para saber como se portar de forma pertinente e competente.

No entanto, o enquadramento necessário para a análise das interações de candidatos com uma banca examinadora nada tem de cotidiano. Aqui tratamos de um outro tipo de situação social, que possui como diferença fundamental, em relação ao cotidiano, a institucionalização de 
suas propriedades cerimoniais. Goffman (1961:7) distingue as interações, sob este critério, entre focalizadas e não focalizadas.

As interações focalizadas, mais identificadas com o tipo de situação que se quer analisar aqui, possuem certas propriedades que lhes conferem um estatuto - e uma abordagem, portanto - particular: "Exemplos de tais propriedades incluem constrangimento, manutenção da pose, capacidade de comunicação verbal dirigida, a adesão a um código que observa a tomada e concessão do papel de orador, e a alocação de uma posição espacial" (Goffman, 1961:11). O autor assinala que a participação nas interações focalizadas - que ele chama também de encontros (encounters) - é fundada na adesão a um código essencialmente cerimonial: regras que organizam constrangimentos de discrição e postura, de comunicação verbal e posicionamento espacial.

No que nos interessa, as normas - mesmo, e sobretudo, as normas cerimoniais - são compostas de expectativas e obrigações, e é aqui que a metáfora do jogo começa a ganhar sentido. Num concurso público, como num jogo de $\operatorname{cartas}^{6}$, o domínio das regras e a perícia em transformá-las em meios de sucesso são os fatores decisivos para determinar o vencedor: "Eu volto ao pressuposto de que, como qualquer outro elemento da vida social, um encontro exibe uma regularidade sancionada oriunda de obrigações cumpridas e de expectativas realizadas, e que é aí que reside a sua estrutura" (Goffman, 1961:19). Nas palavras do autor, é a correspondência às expectativas e o cumprimento das obrigações que estruturam as interações focalizadas. Aqui podemos ver a primeira conversão da sociabilidade em uma verdadeira competência estratégica.

No cotidiano, a perícia na correspondência às expectativas e o cumprimento das obrigações contribui para o acúmulo reputacional e relacional, tornando-nos "sociáveis". No entanto, as questões em torno do desenrolar das interações também são importantes aqui, e para distingui-las daquelas que enfrentamos cotidianamente, a institucionalização das normas cerimoniais não é suficiente. Um candidato que passa por um concurso público tem muito mais em jogo que a sua reputação. Precisamos da incorporação de dois outros elementos para passar ao quadro do jogo: o risco e a consequencialidade.

\section{GOFFMAN E A METÁFORA DO JOGO}

Os concursos representam concretamente o acesso aos cargos públicos e a tudo o que eles trazem concretamente. A sociologia que tento mobi- 
lizar remete a dois movimentos fundamentais: antecipação e adaptação. O cerne destes dois movimentos não está ligado a um saber, ou mesmo a um savoir-faire, mas à capacidade de apreender uma rede de expectativas e de se adaptar a ela (Gaïti e Sawiki, 1997:10).

Para construir sua noção de jogo como quadro analítico de certas situações sociais, Goffman fala de "ação" num sentido não parsoniano, mas evocando o uso corrente ordinário do termo. Nos Estados Unidos, o termo action é comumente empregado para designar situações arriscadas ou até mesmo perigosas. Em oposição aos momentos em que nós "matamos tempo", o autor quer desenvolver uma abordagem sobre as situações envolvendo risco e consequencialidade (fatefulness e consequentiality). Por risco devemos entender que a ação perpetrada pode acarretar em desdobramentos que se dividem, grosseiramente, em desejáveis e indesejáveis, e que podem ser relativamente previsíveis quando da decisão da escolha do curso de ação pelo jogador. Na situação que se pretende analisar - um concurso público - dois são os desdobramentos possíveis: passar ou não passar. Entretanto, para que se configure um jogo, não é necessário apenas haver o risco de ganhar ou perder, mas é necessário que igualmente o que se ganha ou o que se perde seja, em alguma medida, considerado importante para os jogadores. É o que Goffman chama de consequencialidade, o peso do resultado negativo ou positivo para aquele que assumiu o risco. Num concurso público, a possibilidade de acesso ao cargo desejado e a seus benefícios representa o segundo elemento da situação.

Podemos imaginar algumas consequências quando de nosso envolvimento num jogo. Na maioria das vezes - incluindo a situação que se quer analisar aqui -, participar do jogo é uma questão de escolha, diferentemente do teatro, na medida em que não se escolhe um engajamento num cotidiano.

Em primeiro plano, é necessário estimar qual o valor que cada jogador atribui ao sucesso, assim como o valor que cada jogador estima perder no caso do fracasso. Em segundo plano, cada jogador avalia suas chances, quer dizer, a relação entre os meios de sucesso que cada um estima possuir e o grau de risco que cada um estima assumir. Passar num concurso público não é uma verdadeira questão para qualquer pessoa, e mesmo para muitos que gostariam de se tornar funcionários públicos a objetivação desta vontade não acontece em virtude da não adoção deste curso de ação. Nosso universo de jogadores é, então, composto por 
todos aqueles que desejam se tornar funcionários públicos e que objetivam esta vontade através da elaboração e realização de uma estratégia de sucesso.

Um desdobramento destas situações que concerne a este trabalho toca a questão do controle físico e emocional diante de uma situação de stress. Temos o hábito de associar a manutenção do autocontrole sobretudo face ao perigo - como traço de alta qualidade moral, como a medida dos homens segundo Hemingway: a capacidade de ser gracioso sob pressão. As implicações físicas da manutenção da postura sob stress são ligadas à capacidade de um minucioso controle muscular. Com efeito, o impacto da situação pode fazer o jogador se trair por alguns gestos, expressões faciais, maneiras de falar ou de escrever... No limite, o que pode acontecer é um bloqueio físico ou psicológico, ou mesmo um colapso, ocasionando a perda dos sentidos. Goffman mesmo dá alguns exemplos interessantes: os surfistas e os toureiros possuem por princípio de atividade a manutenção da pose diante de condições adversas, certos políticos têm por principal competência a serenidade discursiva mesmo enfrentando uma plateia crítica, e, enfim, as provas escolares, que têm por principal escopo o teste das capacidades dos alunos de cumprir duras tarefas em tempo controlado (Goffman, 1967:214-238). Quando fiz uma etnografia das provas orais do concurso da magistratura francesa em 2007 e 2008, pude perceber como se objetivam o stress e o nervosismo dos candidatos através de gestos ou pequenas alterações na fala. Pude mesmo acompanhar a candidata que durante o tempo de preparação da prova oral de Cultura Geral (última prova do concurso) perdeu os sentidos e foi retirada de ambulância (Fontainha, 2011:322).

Entretanto, é em torno da informação que nosso jogo ganha a maior parte do seu sentido. Voltando ao teatro, a permanente troca informacional entre ator e receptor no cotidiano constrói pouco a pouco, o próprio sentido da interação. A questão que se deve colocar é relativa à eventual capacidade de adquirir, de controlar e de encobrir estas informações ou, nas palavras de Goffman: "Neste artigo, quero explorar uma capacidade humana geral, em termos das concepções que temos de seus limites físicos e sociais: a capacidade individual de adquirir, revelar e ocultar informações" (1969:4). Nas situações que se quer examinar, temos, de um lado, uma banca que quer adquirir informações capazes de serem traduzidas em uma nota, e, de outro lado, candidatos com o interesse de veicular as informações que julgam mais benéficas 
para a produção desta nota. Temos, então, um observador dependente daquilo que ele pode apreender de um objeto; encontramo-nos numa avaliação na qual a informação se torna estratégica e jogos de expressão se realizam (ibidem:10-11).

Neste ponto é interessante notar que a apreensão que Goffman faz do vocabulário do jogo em substituição ao do teatro não é meramente ilustrativa, mas analítica. Ele passa a utilizar o termo observador e objeto no lugar de ator e receptor, e expressão no lugar de informação. Esta inversão lexical reforça uma diferença fundamental entre o teatro e o jogo: a expressão é a informação disponibilizada pelos participantes, provocando duas consequências fundamentais: de início, a informação disponível aos participantes do jogo é submetida à interpretação contextual segundo as normas que constituem o sentido do jogo e, em seguida, a aquisição desta informação obedece a um processo complexo de movimentos e contra movimentos entre observador e objeto.

Sobre a interpretação contextual é necessário dizer que em todos os jogos existem situações que são plenamente compreensíveis a todos aqueles que, ao menos, conhecem a especificidade cerimonial que estrutura o sentido próprio do jogo. Então, para os participantes, ou mesmo observadores, que sabem do que se trata, uma expressão é interpretada como um movimento numa sequência estratégica, para além de um simples gesto comportamental. O exemplo do bridge, de Garfinkel, ilustra bem este propósito:

Para ilustrar, os jogadores de bridge não respondem às ações uns dos outros como atos comportamentais. Eles não tratam o fato de que o outro jogador retira uma carta de sua mão e a coloca sobre a mesa como o evento "colocando abaixo um papel cartonado" ou "efetuando a tradução da posição de uma carta", mas sim através da tradução da posição da carta do jogador sinaliza que "ele tem como jogada o ás de espadas como primeira carta do truque". Do ponto de vista dos jogadores a pergunta "o que pode acontecer" é para ele corretamente decidida nos termos dessas regras. (1963:194 apud Goffman, 1961:26)

Sobre o modelo "observador/objeto" é necessário sublinhar que, em geral, as tarefas do jogo são divididas entre aqueles que buscam e aqueles que fabricam ou escondem expressões. Em suma, o papel do observador no jogo é desvendar a informação desejada sobre o objeto que, por sua vez, tem por papel a fabricação e a manutenção da expressão que lhe é mais favorável. Entretanto, esta divisão de tarefas não é arbitrária, mas caminha no mesmo sentido dialético e reflexivo do flu- 
xo de informações que circula entre ator e receptor. O observador (a banca examinadora) também pode se tornar o alvo de apreciações, e o objeto (o candidato), um caçador de expressões. Já pude constatar como os candidatos à magistratura francesa se preparam em função de uma banca, buscando informações sobre a vida profissional e os centros de interesse dos membros da mesma (Fontainha, 2011:277-283 e 304-312). Assim, a grande questão aqui é: o desejo de agregar o melhor valor de face possível, mesmo na hipótese da rejeição do valor de face e da busca de expressões imunes à fabricação e à dissimulação. A engenharia de expressão consiste, aqui, na veiculação da expressão pertinente pelo objeto e na busca de fraquezas desta pertinência pelo observador.

Mas quais são as fontes de informação com as quais podemos contar para acessar a expressão? Qualquer fonte pode ser utilizada e, normalmente, as pesquisas empíricas surpreendem os observadores desavisados $^{7}$, mas Goffman (1969:20-28) lista quatro delas, incontornáveis para este trabalho. A primeira é a expressão psicológica: expressões faciais, mãos trêmulas, pequenas gagueiras, enfim, todo sinal físico que pode indicar a objetivação da incerteza, da insegurança, ou, em suma, o medo da descoberta da descontinuidade entre o ser real e o ser reivindicado. A segunda é o comportamento: os dados de padrão comportamental que podem distinguir alguém da pessoa que ele reivindica ser, como a idade, o sexo, a origem geográfica ou social, o sotaque etc. A terceira é a correção cênica: pequenas correções e atualizações que podemos realizar para restaurar a ordem da interação, como breves cumprimentos, saudações, desculpas ou pequenas pausas.

A quarta, e mais potente, é a "etiqueta" de identidade: sinais oficialmente reconhecidos que ligam um indivíduo à sua biografia. Aqui os exemplos podem ser numerosos. Goffman (1969:96) utiliza o recurso que o psiquiatra faz ao dossiê do novo paciente antes da consulta. Já tive a oportunidade de demonstrar o uso estratégico que os candidatos ao concurso da magistratura francesa fazem de seus dossiês de candidatura (Fontainha, 2010:117-138). A partir da análise de 750 dossiês, pude observar que apenas os diplomas com menções valorosas eram enviados junto com a documentação obrigatória. Alguns deles encaminhavam o curriculum vitae, e até mesmo boletins do ensino secundário com comentários elogiosos de professores. Igualmente, nos inquéritos de moralidade não era raro encontrar a transcrição feita pela polícia de depoimentos triunfalistas sobre a vontade de passar no concurso e de ser magistrado, e dos esforços despendidos para tanto. 
Na verdade, cada um de nós é cercado de "etiquetas": uma carteira de identidade, um boletim escolar, uma certidão de casamento, sem contar tudo aquilo que pode ser achado por meio de ferramentas como a internet.

Para prosseguir na qualificação de nosso jogo é necessário distinguir os movimentos mais frequentes. O movimento involuntário (unwitting move) é aquele em que o objeto age sem se orientar pelo observador, o que significa dizer que se trata de um movimento praticamente fora do jogo. O movimento ingênuo (naive move) ocorre quando o observador toma o objeto tal como ele se reivindica, ou o "compra" por seu valor de face. Porém, o movimento mais importante do jogo é o movimento de controle (control move): é o esforço intencional do objeto para impressionar um observador, ou a ação consciente deste para desestabilizar aquele.

O movimento de controle, quando usado pelo objeto, se chama movimento de cobertura (covering move), e consiste na utilização de qualquer recurso estratégico para se reivindicar expressões valorizantes e esconder expressões desvalorizantes. Todo esforço de responder a uma questão sobre um tema que dominamos pouco, toda tentativa de esconder um diploma medíocre, ou mesmo um sorriso dado num momento de desespero, são exemplos de movimentos de cobertura. Por outro lado, todo ato do observador tendente a desconstruir os movimentos de cobertura chama-se movimento de descoberta (uncovering move). Toda verificação, toda tentativa de desestabilizar um candidato, toda questão que chamamos correntemente de "pegadinha", são exemplos de movimentos de descoberta. Vejamos, então, como Goffman descreve a "pegadinha" (trick question): uma pergunta à qual a resposta parece, mas não é, aquela que poderia ser imaginada pelo objeto que não sabe a resposta, mas que gostaria de dar a impressão de que sabe (Goffman, 1969:18).

O caráter negativo do jogo não é o único, tampouco o mais importante. Os esforços para impressionar um observador ou para desestabilizar um objeto são apenas uma dimensão dele. Na verdade, o crédito não é unicamente ligado à capacidade de se manter um valor de face que nem sempre é estável. O maior crédito que podemos mobilizar neste jogo é relativo às declarações (avowals). Todo engajamento, toda assunção de riscos, toda escolha irretratável de um curso de ação é tomado como um movimento de jogo (Goffman, 1969:113). 
Assim, as declarações, enquanto elementos fortes de objetivação de um engajamento estratégico, representam mais do que a palavra de um jogador, pois é necessário que este, a partir das evidências motivadas pelas regras do jogo, indique de maneira irreversível sua escolha por um curso de ação que permita ao observador o teste de sua estabilidade. Nas provas jurídicas, sobretudo as orais, não é incomum a provocação dos candidatos para que se posicionem em favor de uma das correntes doutrinárias envolvendo uma questão. Ao declarar adesão a uma das correntes, o jogo se institui e o candidato será avaliado pela sua capacidade de manter a estabilidade da linha de ação que escolheu. Ao tentar se esquivar ou não declarar adesão a nenhuma das correntes, o candidato, tentando escapar da declaração, não fornece aos examinadores critérios claros pelos quais ele poderá ser julgado. Desta forma, não declarando, não assumindo riscos, não marcando na sua performance uma postulação de ação estável, ele comete o maior dos erros de um jogador: a quebra da ordem ritual que estrutura um jogo. É desta maneira que banca e candidatos construirão a lógica da seleção ao curso da mesma.

Duas últimas considerações nos faltam acerca da metáfora do jogo. A primeira é referente ao seu caráter derivativo: é evidente que o jogo herda as categorias fundamentais do teatro. Assim sendo, o quadro incorpora um aspecto constrangedor para esta abordagem: o foco no imediatismo das interações face a face entre ator e receptor. No entanto, quando se trata de um jogo, observadores e objetos interagem também por intermédio de outros veículos, como cartas, documentos, e-mails etc. Isto por duas razões básicas: de início, o acesso à expressão não se dá unicamente quando da presença imediata; em seguida, várias situações - para além dos momentos em que observador e objeto se encontram face a face podem compor o todo social de um jogo. Afirma Goffman:

Qualquer contato que um grupo tenha com um indivíduo, quer face a face ou mediado por dispositivos como os e-mails, vai dar o acesso da expressão a terceiros. Imediatismo, então, não determina o limite analítico para o estudo da expressão (1969:5).

Em se tratando de concursos públicos, devemos tomar a prova escrita como o veículo de expressão por excelência entre candidatos e a banca examinadora.

A última consideração a ser feita concerne à evidente presença de uma banca examinadora no jogo. À diferença de vários jogos em que os adversários se afrontam diretamente, lidamos aqui com um comitê de pe- 
ritos que tem por tarefa a avaliação individual das performances de cada candidato. Não se trata de pessoas encarregadas da aplicação de um barema de avaliação (como a banca da patinação artística), ou da verificação permanente da aplicação de regras escritas (como o juiz de futebol). Nos concursos públicos, cada candidato terá sua performance individual objetivada numa linguagem acadêmica sob a forma de uma nota para, após, ser formada uma ordem comparativa. Sobre o poder de intervenção dos observadores sobre a competição entre objetos, afirma Goffman:

Além disto, na maioria das decisões proferidas pelos juízes a aplicação de uma compensação não se baseia em pura coerção, como acontece quando a natureza chama a entrar em sintonia com as questões da vida e da morte. Outros fatores estão envolvidos: o sentimento de que os juízes são sagrados e seu mundo não deve ser abertamente desafiado, a capacidade dos juízes de infligir penas extras de um tipo mais acentuado tal que o seu julgamento deva ser rejeitado, e as penas ainda mais acentuadas se esta, por sua vez, for rejeitada, e assim por diante, eventualmente culminando presumivelmente em decisões aplicadas fisicamente. Em muitos casos, então, o perdedor de um jogo está em uma posição de declínio, pelo menos temporariamente, e aceitar cooperativamente o julgamento contra ele pode valer a pena enquanto ele faz isso. (1969:117-118)

Miaille, quando de seu artigo sobre as predisposições ao corporativismo na seleção dos magistrados franceses (2005:218-245), usou a revalorização de sua experiência na banca do concurso como fonte de dados, muito embora tenha se valido sobretudo do conceito de capital simbólico de Bourdieu para analisar a medição do desempenho dos candidatos por ele e por seus colegas examinadores. Já investiguei as interações no seio mesmo da banca examinadora do concurso da magistratura francesa (Fontainha, 2009:55-67) e pude constatar que a competição profissional entre professores de Direito e magistrados com a forte primazia acadêmica naquele país - tem nítidas implicações na dinâmica das provas, sobretudo das provas orais.

\section{A TEORIA EM AÇÃO: 0 "GRANDE ORAL" DO CONCURSO DA MAGISTRATURA FRANCESA}

Como observa Joseph, o situacionismo metodológico é ferramenta essencial do interacionismo goffmaniano (2000:89-91). Ainda que se possa 
discutir a natureza do termo "microssociologia", não se pode negar a importância da descrição densa de quadros interacionais como a principal fonte de dados em estudos como este. Assim, este artigo prossegue exibindo uma etnografia realizada por mim nos anos de 2007 e 2008 em Paris, durante a mais "temível" das etapas do concurso da magistratura francesa: a prova oral de Cultura Geral, também conhecida como "Grande Oral", ou, na forma nativa, Le Grand O. Entendamos um pouco melhor a arquitetura deste concurso, e como o "Grande Oral" se encaixa nela, antes de partirmos para os dados propriamente ditos ${ }^{8}$.

Nosso foco aqui será a segunda parte da prova, em que candidatos e banca examinadora interagem por 15 minutos. Esta parte se segue à apresentação de 15 minutos feita pelo candidato sobre um tema ou um texto curto que ele mesmo sorteia de uma lista, após uma hora de preparação. Durante a apresentação do candidato, o turno de fala não é uma questão: o candidato fala sozinho e o presidente da banca apenas o interrompe na eventualidade de ultrapassagem dos 15 minutos. $\mathrm{Na}$ segunda parte, a interação dos candidatos com a banca torna-se muito dinâmica. No entanto, a atividade não é esperada dos candidatos, apenas a reatividade. É papel da banca fazer perguntas.

Na etnografia apresentada a seguir, reagruparei as situações mais distintivas da demonstração pretendida. Os candidatos observados serão representados como $C 1$ até $C 31$, e os membros da banca pela letra $J$ seguida do seu último sobrenome. Estes 31 candidatos fizeram suas provas nos dias 20 e 21 de novembro, 4 e 5 de dezembro de 2007, e 13, 14 e 15 de outubro de 2008. Em três formações diferentes, atuaram como jurados: Sra. Ambroise-Casterot (professora de Direito da Universidade de Nice); Sr. Varinard (professor de Direito da Universidade de Lyon 3); Sr. Charruault (magistrado da Corte de Cassação - presidente da banca); Sra. Bellivier (professora de Direito da Universidade de Paris X); Sr. Dillange, substituto do Procurador-Geral da Corte de Apelação de Paris); Sr. Legeais (professor de Direito da Universidade de Nice); Sr. Dauchy (professor de Direito da Universidade de Lille II); Sr. Chabanol, conselheiro de Estado; e Sra. Crédeville (magistrada da Corte de Cassação - presidente da banca).

A etapa interativa do "grande oral" começava sempre por uma frasegatilho dita pelo presidente com o objetivo de agradecer a apresentação do(a) candidato(a) e marcar a transição, como: "muito obrigado, senhorita, agora passemos às perguntas". Em seguida o presidente da 
banca passava a palavra para cada jurado ou para si mesmo, que faziam perguntas.

Entretanto, mesmo tão institucionalizado o turno de fala, não era rara uma espécie de cooperação entre os jurados ao longo de uma mesma linha de questionamento ao candidato. Por razões propriamente interacionais que veremos a seguir, os jurados tinham por hábito, a todo tempo, se interromper e cruzar perguntas pertinentes à linha de questionamento desenvolvida. Assim, esta etapa da prova é marcada por golpes e contragolpes, na lógica de provocação-reação. Do ponto de vista cerimonial, a posição dos jurados não é fácil. Imaginação e raciocínio rápido são necessários para realizar a tarefa de forma pertinente, uma vez que a continuidade do exercício é de sua responsabilidade.

Dois são os meios observados de garantir a perícia na fluidez da prova: o recurso a temas permanentes e a colaboração entre jurados. O primeiro, geralmente tratado pelo termo "xodó"9 de cada jurado, constitui um forte elemento de realização interacional: é o recurso a temas conhecidos de cada um, o que impede silêncios ou "bloqueios" da parte dos que devem provocar a continuidade da interação. Os exemplos mais marcantes da aplicação desta técnica foram: a utilização da história russa pela Sra. Ambroise-Casterot, a referência ao trintenário da morte de Elvis Presley pelo Sr. Charruault, e as perguntas sobre a obra de Ingmar Bergman feitas pela Sra. Bellivier.

Quanto à colaboração entre os jurados, uma vez que as perguntas são curtas e rápidas, os responsáveis pela continuidade do exercício reenquadram permanentemente a pertinência contextual da interação, fazendo de tudo o que é dito uma referência sólida para a pergunta seguinte. Sublinho que a referência pode vir da resposta do candidato ou da pergunta de outro jurado.

O "bom" emprego da colaboração será objeto de várias análises a seguir. Por ora, consideremos o uso de outras técnicas de descreditamento dos candidatos. O contexto deste exercício chama o quadro compreensivo da alternância entre golpes de controle e golpes de descoberta. Várias eram as técnicas mediante as quais se tentava buscar a impertinência ou insuficiência da resposta do candidato. Por vezes o descreditamento toma formas mais coletivas e evidentes. Não me refiro às vezes em que o candidato faz uma piada bem colocada, mas de situações nas quais o riso coletivo dos jurados desestabilizava e descreditava o candidato: 
JChabanol - Quantas vítimas em Hiroshima?

C25 - Não sei, todo mundo?

[gargalhadas dos jurados]

Aqui é necessário tratar de outra técnica: a do "não sei". Não era raro o uso desta expressão antes de uma resposta que o candidato considerasse inadequada, na tentativa de minimizar seu peso descreditante. $\mathrm{O}$ uso desta técnica por parte dos candidatos é delicado; no caso citado, não ajudou. O riso coletivo pode, por vezes, ser provocado por um dos jurados, como no caso abaixo:

JCasterot - Então, dizemos "magra" ou "fina" ${ }^{10}$ ?

C11 - São dois lados da mesma moeda.

JCharruault - Então, magra de frente e fina de costas? [todos os jurados riem] Diga, de todas as mulheres não retocadas por photoshop, qual é a mais bonita?

C11 - Brigitte Bardot.

JCharrualt - Hum, voilà...

É necessário notar que não há nenhuma implicação substantiva na piada. A distorção da metáfora do candidato produz, ao contrário, o endurecimento das condições de interação. O riso coletivo pode mesmo ser provocado entre jurados:

JDauchy -É necessário pregar o atestado de saúde na porta dos gabinetes dos juízes?

JCrédeville - Ao menos o da saúde mental... [todos os jurados riem]

C27 - Não, me parece excessivo...

JDauchy - Você está dizendo que uma decisão política é mais importante que uma decisão jurídica?

C27 - Não, eu não disse isso...

JDauchy - Você não tem medo de assédio num meio tão feminino? (o candidato era homem)

C27 - Curiosamente, não [todos os jurados riem]

JDauchy - Por que "curiosamente"?

C27 - Não sei, é minha experiência pessoal.

Para além dos risos coletivos, a maneira mais simples de descreditar um candidato é o anúncio direto e claro do seu erro:

$$
\begin{aligned}
& \text { JDauchy - Como traduzimos "law"? } \\
& \text { C17 - "Lei"? } \\
& \text { JDauchy - Não, "Direito"! }
\end{aligned}
$$

Situações como a do exemplo acima ocorriam com frequência. A palavra "não" era assim empregada para anunciar publicamente o descre- 
ditamento, ou, ainda, para afirmar o uso excessivo ou impertinente da técnica do "eu não sei":

JCharruault - Onde morreu Elvis Presley?

C12 - Eu não sei.

JBellivier - Memphis. Quem mais morreu em Memphis?

C12 - Eu não sei.

JBellivier - Martin Luther King, conhece?

C12 - Ah, sim...

JBellivier - Esqueçamos o "king". Quem foi Martinho Lutero?

C12 - Eu não sei.

JVarinard - Não, não...

A intervenção do Sr. Varinard exprime uma das regras claras deste "jogo": o limite do uso da técnica do "eu não sei" é a expectativa normativa mínima da banca. No caso acima, era legítimo o uso da técnica nas demais perguntas, mas não foi tolerada quando se perguntou quem foi Lutero.

Quase toda expressão utilizada pelos candidatos que pudesse ser utilizada como símbolo descreditante pelos jurados entrava no jogo, na maioria das vezes, sem nenhuma implicação substantiva. C31, na sua exposição oral, utilizou o artigo definido "o" para designar a SFIO, e durante a conversação, depois:

JChabanol - O que é SFIO?

C31 - Sessão Francesa da Internacional Operária.

JChabanol - Então porque "o" SFIO?

C31 - Perdão, a SFIO.

JChabanol - Fale-nos dela.

C31 - (...) então Léon Blum, após Jean Jaurès (...) então o SFIO...

JChabanol - Ah!

C31 - Perdão, a SFIO...

Aqui fica claro que qualquer conhecimento substantivo em torno da SFIO é irrelevante para os golpes de descoberta desferidos pelo jurado. Quando está a serviço do descreditamento de um candidato, a colaboração entre os jurados pode tomar reflexivamente uma capacidade de adaptação contextual sofisticada:

JBellivier - Quem é o maior antropólogo francês?

C26 - Claude Lévi-Strauss.

JBellivier - Ele é vivo?

C26 - Não.

JBellivier - Sim, ele fez 100 anos este ano, mas está vivo.

JDauchy - O juiz deve ser um pouco antropólogo? 
C26-Hum...

JDauchy - O juiz deve explicar sua decisão?

C26 - Não.

JChabanol e - Perdão!?! [os dois juntos]

JDillange

C26 - Não... eu tinha pensado na prestação pública de contas...

JCrédeville - Existem decisões não justificadas?

C26 - Sim, as proferidas em Cassação [todos os jurados riem, olhando para a Sra. Crédeville, juíza em cassação]

JCrédeville - Eu tinha pensado no Júri...

Um último ponto a observar nos golpes de descoberta é o uso recorrente da ironia, que provoca um efeito devastador na moral do candidato. Por ironia me refiro ao que é dito, mas se querendo afirmar justamente o contrário, buscando o efeito contextual de confrontar o candidato com uma grave reprovação por parte do jurado:

C1 - Os Direitos Humanos não são completamente respeitados na China [risos].

JCharruault - Os Direitos Humanos não são com-ple-ta-men-te respeitados na China, tá bom! [acentuando fortemente a palavra "completamente"].

C1 - Não, não... quero dizer que os Direitos Humanos não são respeitados na China.

Outra técnica de inquirição consiste na alimentação das expectativas normativas legitimadas por expressões pessoais ou sociais dos candidatos. Não estou falando da pertença de classe, étnica ou religiosa. As expressões simbólicas mais evocadas eram o nome, o sobrenome e, às vezes, o endereço, impressos na capa do dossiê de candidatura, que ficava em cima da mesa da banca examinadora.

Após ler o dossiê de C23, o Sr. Dauchy pergunta: “Lille ou Aix? Norte ou Sul?". Por vezes este uso pode ser mais direto:

JVarinard - Você é filha de viticultor, fale-nos do movimento dos viticultores de 1950.

C4 - O senhor quer dizer de 1905 ?

JVarinard - Não, 1950!

Aqui a expressão evocada visa adicionar à pergunta do jurado uma expectativa normativa legítima de obrigatoriedade de pertinência da resposta. Efetivamente, a referência ao nome ou sobrenome era feita de forma bem direta:

JCharruault - Você tem um homônimo célebre?

C1 - Sim, um pintor, mas eu não conheço seus quadros. 
A resposta demonstra claramente a compreensão do sentido da pergunta, ela é pertinente. No entanto, ela seria marcada pela competência estratégica se, em conhecendo a possibilidade do uso desta homonímia pelo jurado (uma regra do "jogo"), o candidato se antecipasse e preparasse uma ficha sobre o pintor em questão, como fizeram vários outros candidatos:

JCharruault - Você se chama "Eurídice", o que você sabe de "Orfeu"?

C24 - [Não consegui anotar exatamente o que foi dito, mas a candidata resumiu a lenda grega].

JCharruault - A estória de Orfeu inspirou músicos?

C24 - Sim, Monteverdi primeiro, em seguida Glück, e depois Offenbach.

Desta forma, pretendo demonstrar empiricamente o que chamo de ferramenta cognitiva, competência interacional e realização estratégica. Para além de uma invenção acadêmica para explicar dinâmicas de concursos, a etnografia permite uma melhor compreensão das invenções dos atores destes processos para tornar o mundo mais compreensível e seus interesses mais realizáveis, ou, ainda, como se põem em marcha invenções teóricas de sistemas de interpretação não acadêmicos (Parnell, 2002:34).

Uma situação parecida ocorreu com a candidata chamada "Elsa":

JChabanol -Se, saindo daqui... câmeras... microfones... "como foi o Grande Oral?"

C29 - Hum... não sei, é difícil...

JChabanol - Nada? Nada além de "olhem meus belos olhos"?

C29-Hum...

JChabanol - Por que eu faço referência aos seus olhos?

C29 - Talvez graças ao "Olhos de Elsa", um poema...

JChabanol - Você conhece este poema... uma parte talvez?

C29 - [ela declamou uma boa parte do poema de Louis Aragon].

Passo a outro aspecto do Grande Oral: o descreditamento da técnica do "eu não sei" pelo uso de "pistas". Uma pista é uma ferramenta interacional poderosa, pois restabelece a pertinência da pergunta e, sobretudo, devolve o turno de fala ao candidato. Outra dimensão da pista é o jogo de adivinhação, em que o candidato é provocado a responder, mantendo a interação até que a satisfação do jurado, pela adequação ou inadequação da resposta ocorra. Uma das grandes competências no grande oral é a capacidade de adaptação contextual, pois por vezes os jogos de adivinhação reenviam a outros universos contextuais, como na situação a seguir: 
JCasterot - Qual Tzar foi morto em 1917?

C19 - Eu não sei...

JCasterot - Vamos festejá-lo amanhã.

C19 - Alexandre?

JCasterot - Amanhã é dia de São Alexandre?

C19 - Ah, não... Nicolau!

Em outra situação, o uso do desvio contextual e da pista serviu apenas para confirmar a insatisfação do jurado diante da técnica do "eu não sei" usada quando de uma pergunta cuja resposta o candidato era obrigado a conhecer:

JDauchy - Quando começa a História?

C19 - Eu não sei.

JDauchy - O que tem antes da História?

C19 - Eu não sei.

JDauchy - AN-TES da HIS-TÓ-RIA...

C19 - A pré-História?

No diálogo abaixo, pude perceber a colaboração direta entre jurados, o emprego da pista e, da parte do candidato, a manutenção dos seus avowals iniciais:

JCasterot - Quem compunha para Sergio Leone?

C20 - Ennio Morricone.

JCasterot - E para Star Wars?

C20 - John Williams.

JDillange - Um outro compositor do cinema italiano?

C20 - Hum...

JLegeais - Trabalhou muito com Fellini...

JCharruault - Um certo Nino...

C20 - Hum...

JCharruault - Nino Rota, conhece?

C20 - Não.

Outra técnica muito utilizada é a dos avowals. Jurados e candidatos a utilizam mutuamente e reconhecem sua pertinência contextual. É evidente que os jurados querem que os candidatos a utilizem para vincular suas respostas, e os candidatos a utilizam para se engajar ou se desengajar em determinados temas. Vejamos abaixo:

JCasterot - O que você acha da música eletrônica?

C4 - Eu não conheço música eletrônica.

Um observador ingênuo diria que o candidato respondeu de forma impertinente. No entanto, esta é uma maneira competente de se desengajar de um tema que eventualmente não é de seu conhecimento. A jura- 
da, por sua vez, deve seguir outra linha de inquirição ou manter esta, mas sem poder exigir do candidato legitimamente respostas pertinentes. Vejamos a seguir uma situação em que jurado e candidato usam a técnica:

JCharruault -Se você pudesse escolher um ano para viver na França, qual seria?

C1 - O ano da liberação do aborto.

Igualmente, um olhar desavisado trataria a resposta como impertinente, uma vez que a pergunta deveria ser satisfeita com um ano expresso em numeral. No entanto, ciente das regras do jogo, o candidato pertinentemente pula uma etapa do rito de interação e já lança seu avowal, o tema que se engaja a tratar com competência pelo restante da interação. Muito embora cada etapa interativa ocorra muito rápido, os atores envolvidos estão plenamente cientes do processo, apenas não o organizam e descrevem como eu o faço.

Por vezes, a técnica do avowal pode servir simplesmente como uma armadilha para o candidato para esconder a necessidade do jurado de mudar seu tema, uma vez que é dele a obrigação de dar impulso à interação. Não basta imaginar que as estratégias dos candidatos são de conhecimento dos jurados, o contrário também ocorre. Assim, a técnica do avowal é muito utilizada para montar uma linha de inquirição que pode constituir uma armadilha. Porém, pode ocorrer que os candidatos caiam nesta armadilha voluntariamente, quiçá alegremente, sobretudo dependendo da maneira que se cai nesta armadilha.

Uma outra situação mostra a importância da técnica do avowal, mas desta vez vários jurados a utilizarão para intervir em colaboração. Assim, a pertinência da técnica é sua capacidade de criar pontos estáveis de interação, e seu caráter estratégico está no fato de criar uma expectativa legítima:

JDillange - Você mencionou o cinema... qual o outro grande filme sobre o autismo?

C24 - Rain Man.

JDauchy - Se você organizasse um canal para os juízes, você mostraria o quê?

C24 - A vida no subúrbio, nos bairros pobres.

JDillange - Os juízes estão à margem de tudo isso?

C24 - Não, mas um filme como "Entre les Murs"...

JDauchy - Este filme fala de subúrbios?

C24 - Não, de Paris...

JDauchy - E as altas finanças? Os juízes não julgam só a miséria... 


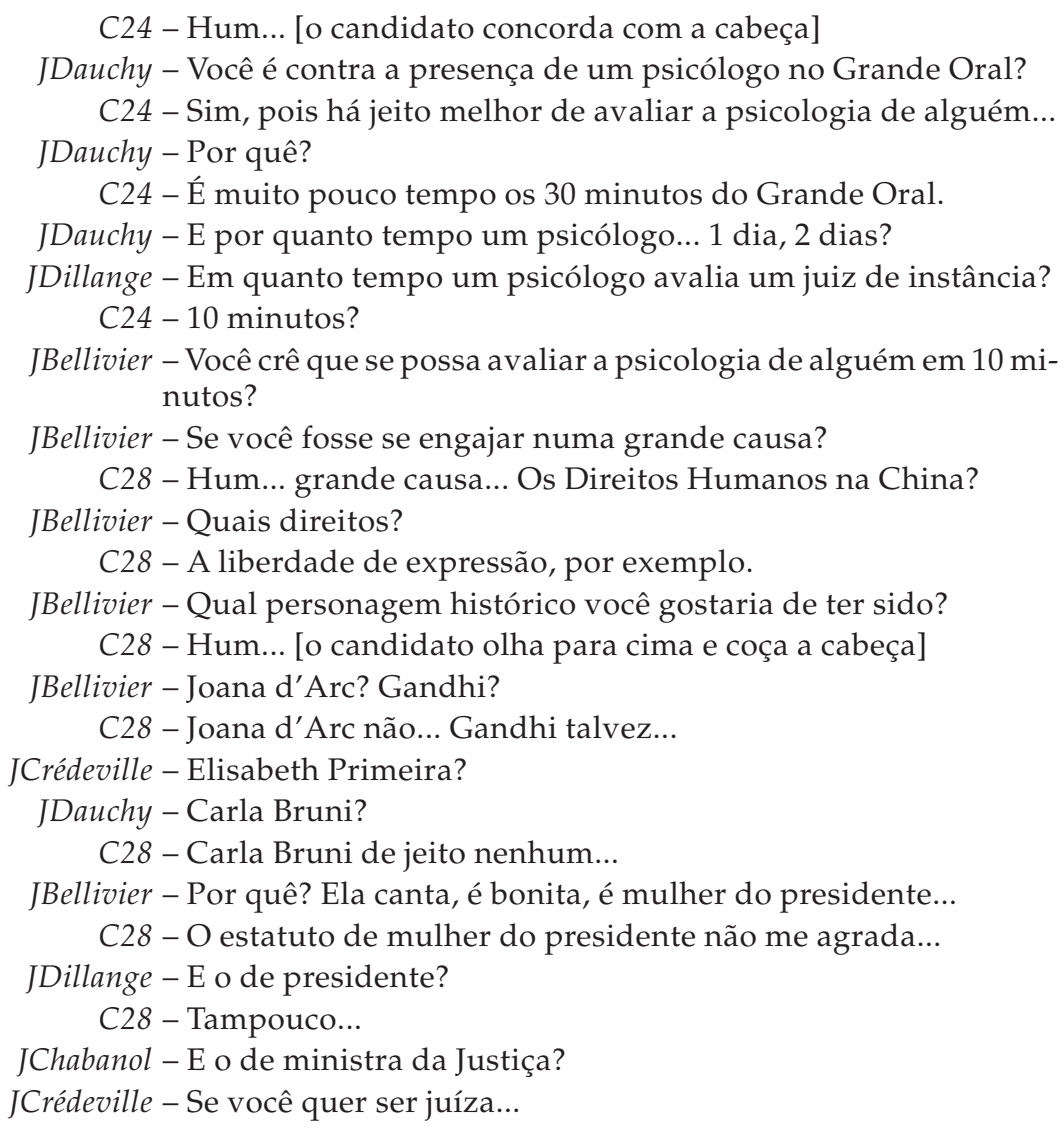

Em outra situação, as técnicas do avowal e da pista dão a dimensão estratégica e cognitiva do exercício:

JCharruault - Qual seu estilo musical preferido?

C20 - O rock-folk americano.

JCharruault - Qual personalidade do rock morreu em Memphis?

C20 - O King, Elvis, há 30 anos.

JCharruault - Quais outras figuras morreram em Memphis?

C20 - Eu não sei...

JCharruault - Um outro King...

C20 - B. B. King?

JCasterot - Saia do tema musical.

C20 - Hum...

JDauchy - "Eu tenho um sonho"...

C20 - Ah, Martin Luther King!

Enfim, o último extrato que utilizarei mostrará o uso de diversas técnicas por jurados e candidatos, deixando claro a que ponto as realizações 
estratégicas podem ser postas em prática numa fração de segundo, e como são extremamente ligadas às particularidades do contexto:

JDauchy - Qual o uniforme dos candidatos aqui? Tailleur e saia pretos?

C32 - Bom, eu diria que sim para me beneficiar, mas não há um uniforme, os candidatos tentam seguir um padrão.

JDauchy - E quem estabelece este padrão?

C32 - O costume.

JDauchy - Voltando aos estádios, "Maracanã" te diz alguma coisa?

C32 - Ah, não...

JDauchy - No país do futebol...

C32 - Brasil?

JDauchy - Por que você disse Brasil?

C32 - Porque, para alguém como eu, que ignoro o assunto, é o que vejo na televisão...

JDauchy - O maior jogador brasileiro?

C32 - Eu não sei... Ronaldinho?

JDauchy - De todos os tempos?

C32 - Maradona? [todos riem, inclusive a candidata]. Voilà, isto confirma o que eu disse: não entendo nada do assunto.

JDauchy - Tá bom. Em que cidade fica o Maracanã?

C32 - Eu não sei...

JDauchy - Que cidades brasileiras você conhece?

C32 - São Paulo...

JBellivier - Esta é a maior, mas há outra mais conhecida...

JDillange - "Eu vou pra"... [cantarolando a canção de Claude François]

C32 - Rio!

JDauchy - Voilà, me diga qual a praia mais conhecida no Rio.

C32 - Eu não sei.

JDillange - Petrópolis, te diz alguma coisa?

C32 - Ah, não...

JBellivier - E "Metrópolis"?

Espero ter demonstrado como algumas categorias que relacionei se apresentam em contexto e em ação através da observação etnográfica, bem como sua adequação analítica. Uma vez mostradas através de um situacionismo metodológico, a reflexividade adiciona o último elemento compreensivo ao que chamo ferramenta cognitiva, competência interacional e realização estratégica.

Outros pesquisadores se interessaram por exercícios muito semelhantes ao grande oral, porém se valendo de abordagens bastante diferentes. Bourdieu, comparando o grande oral da Escola Nacional de Administração ao da Escola Normal Superior, diz que o primeiro 
oscila entre a entrevista oficial, a conversa de coquetel ou a reunião de comissão administrativa, e a prova oral da Escola Normal, um tipo de prova escrita pronunciada oralmente, como uma lição, demandando mais virtudes de clareza e convicção que margem de manobra e presença de espírito (Bourdieu, 1989 apud Miaille, 2005:237).

Miaille vê a submissão à ordem, o equilíbrio e a conciliação, a história e a cultura das civilizações e a negação da autoridade na representação do ofício como as manifestações corporativas dos candidatos ao concurso da magistratura francesa ENM (2005:252-269). Billand, por sua vez, após observar as provas orais do concurso da administração pública local na França, afirma que a prova se situa entre exigências burocráticas, gerenciais e locais (2010).

Muitos observadores tomam o que é dito e feito pelos atores (ou agentes) observados na expressão semântica que pode ser extraída; o sentido da ação ou do discurso encontra-se no universo significativo de uma visão de mundo ou, ainda, num conjunto de representações.

Minha abordagem é bem diferente: o sentido do que é dito e feito é buscado na especificidade do contexto e reflete um estado interacional. Busco, assim, o sentido das ações dos atores na sua common sense knowledge (Heritage, 1984:144), na sua dimensão indexical. O sentido das palavras e dos gestos não pode ser compreendido senão dentro da complexa rede de expectativas, obrigações e realizações práticas. É esta postura que chamo de "deixar o campo falar", que pode soar como apologia ao empirismo, mas que procura, sobretudo, evitar, como disse Cicourel, a postura de pressupor instâncias óbvias da ordem social, chamando-as "problemas sociais" ou "dinâmicas" dos "sistemas sociais", ou, ainda, "variáveis" (Cicourel, 1995:3-4).

\section{CONSIDERAÇÕES FINAIS: UM MODELO SOCIOLÓGICO PARA COMPREENDER OS CONCURSOS PÚBLICOS?}

À diferença de autores que utilizam a Teoria dos Jogos para desenvolver um modelo teórico e aplicá-lo em "casos concretos" ou em "situações reais", meu esforço aqui consiste na reunião de algumas ferramentas conceituais capazes de amplificar um poder de explicação sobre a dinâmica social das seleções por concurso público. A escolha pela abordagem goffmaniana não se deu por acaso: trata-se de um conjunto teórico que não encontra sentido sem o preenchimento com dados empíricos. Quando Goffman decide construir suas categorias a partir do senso comum - eu diria do saber prático, como tomar a noção 
de action num sentido não parsoniano - para estruturar sua Teoria dos Jogos, ele fornece ao pesquisador que a usa uma liberdade criativa enorme. Como na tradição de Chicago, uma Teoria dos Jogos, vinda ela mesma da empiria, não pode ser antecipada ou anterior aos problemas práticos, porque são estes que impõem às teorias a sua compreensão, e não o contrário.

Por fim, cumpre sistematizar o uso desta Teoria dos Jogos para compreensão de concursos públicos em torno dos seguintes eixos:

a) Abordar a seleção por concursos públicos como uma dinâmica e como um processo pede a compreensão do quadro interacional dos candidatos com a banca examinadora.

b) Toda eventual relação de poder entre jurado e candidato deve ser descrita em termos de assimetria interacional.

c) É preciso admitir a hipótese da eventual descoberta do resultado de um concurso como um momento meramente revelador, sem qualquer risco ou consequencialidade.

d) É necessário compreender a população de candidatos a um concurso público como a totalidade daqueles que desejam ingressar na carreira e que se julgam capazes de consegui-lo, o que se traduz empiricamente pelo engajamento em ao menos um dos atos interacionais que compõem o concurso.

e) Um concurso público não compreende apenas a análise do cumprimento de obrigações através de realizações estratégicas, mas também o momento em que as mesmas são elaboradas através do trabalho de antecipação de expectativas.

f) A opção metodológica pela valorização das normas cerimoniais deve desembocar num protocolo de pesquisas adaptado à valorização da deferência e da conduta como fontes de expressão e da objetivação das regras formais que enquadram a seleção.

g) A distinção entre identidade real e identidade virtual é a única maneira de tratar a noção de "candidato-modelo".

h) Por outro lado, este "candidato-modelo" se encontra numa reflexividade contextual: inicialmente, nas expectativas normativas da banca, em seguida no que os candidatos conhecem destas expectativas, e, enfim, na junção da realização estratégica dos candidatos a partir deste conhecimento com o julgamento destas estratégias, caso a caso.

i) Assim, a competência interacional (ou estratégica) é a capacidade de exprimir declarações sustentáveis pela identidade real ou a ca- 
pacidade de realizar competentes movimentos de cobertura ancorados na identidade virtual, assim como a perícia para distinguir qual destes dois meios é o mais adequado e quando o é.

j) Por fim, é necessário um protocolo de pesquisas que leve em conta os elementos essenciais da expressão: as fontes de informação pessoal e social, a busca de toda fonte documental que serve de "etiqueta" de identidade, bem como a observação das interações diretas nas quais poderiam ser encontradas expressões psicológicas, comportamentais ou cênicas.

Dito isto, é necessário estabelecer uma fronteira: por um lado, este quadro é voltado para a compreensão de como são selecionados os funcionários públicos e, por outro, trata-se de uma proposta que só ganha completude pelo seu preenchimento com dados empíricos colhidos em processos de seleção. A única certeza é a de que o quadro ou modelo adotado deve ser soft o suficiente para deixar o campo falar e, assim o fazendo, ele não terá a serventia de confirmar ou negar determinada postura teórica ou metodológica adotada, mas será a fonte de toda a descoberta.

Por fim, é importante localizar os horizontes que esta proposta de pesquisa pretende explorar no seio da sociologia do Direito. Subárea tanto da sociologia como do Direito, compõe um campo de estudos pouco homogêneo, sendo o foco na justiça e nos tribunais seu principal elemento de amálgama. Mesmo diante de um quadro difícil de descrever, pode-se afirmar que há pouco ou nenhum espaço para abordagens construtivistas ou interacionistas. Ressalvados alguns estudos em antropologia do Direito, até então no Brasil as análises finas sobre as práticas cotidianas dos juristas se encontram negligenciadas. Esta deficiência deve ser superada a bem da subárea, que até então tem oferecido quadros filosóficos, essencialmente teóricos, funcionalistas ou deterministas para a análise do fenômeno jurídico. Não nego a importância da teoria, a existência de determinantes estruturais, ou a força explicativa das variáveis "duras" e das noções de "campo", "função" e "estatuto". Entretanto, ainda que tardia, é chegada a hora da abertura da sociologia do Direito a abordagens focadas em conhecimentos finos sobre os contextos nativos, os ritos de interação e as situações onde a ação concreta dos indivíduos produz cotidianamente o Direito na sociedade.

(Recebido para publicação em fevereiro de 2013)

(Reapresentado em em fevereiro de 2015)

(Aprovado para publicação em junho de 2015) 


\section{NOTAS}

1. Para uma conciliação determinista e interacionista na sociologia das profissões, ver The System of Professions: An Essay on the Division of Expert Labor (Abbot, 1988). Esta e as demais citações em francês e inglês aparecerão neste texto numa livre tradução do autor para o português, em respeito às normas da revista.

2. Vários trabalhos foram produzidos sobre o nascimento e o desenvolvimento da primeira geração de sociólogos na Universidade de Chicago. Um dos mais completos é o de Bulmer, intitulado The Chicago School of Sociology (1984). Ver, também, Department \& Discipline: Chicago Sociology at One Hundred (Abbot, 1999) e L'École de Chicago (Coulon, 1992).

3. Para um interessante introito a este desenvolvimento, ver Eber (2004:5-16). Sobre os principais usos da teoria dos jogos em economia, ver Shubik (1982:6-15).

4. Fun in Games (1961:15-81), Where the Action Is? (1967:149-270), Expression Games: An Analysis of Doubts at Play (1969:3-81) e Strategic Interaction (1969:85-145).

5. Ver Détermination du Fait Moral (Durkheim, 1924:49-90).

6. O jogo de cartas e a deliberação de uma banca examinadora são justamente dois exemplos de interações focalizadas por Goffman (1961:18).

7. Numa pesquisa em curso que realizo na Escola da Magistratura do Estado do Rio de Janeiro (EMERJ), dados colhidos em grupos focais apontam para a certeza que possuem os candidatos de que as bancas de concursos como o da magistratura ou o do Ministério Público utilizam redes sociais como o Facebook ou o Orkut para adquirir informações sobre aqueles que chegam à etapa dos exames orais.

8. Esta pesquisa se deu após a realização de trabalho de campo de similar natureza nos cursos preparatórios da Université de Montpellier (Fontainha, 2013a) e na Escola da Magistratura do Rio de Janeiro (Fontainha, 2013b).

9. Do francês dada.

10. Do francês maigre ou mince, que são sinônimas. 


\section{Fernando de Castro Fontainha}

\section{REFERÊNCIAS BIBLIOGRÁFICAS}

ABBOTT, Andrew. (1988), The System of Professions: An Essay on the Division of Expert Labor. Chicago, The University of Chicago Press.

(1999), Department \& Discipline: Chicago Sociology at One Hundred. Chicago, The University of Chicago Press.

ASTRUC, Philippe. (2010), Devenir Magistrat Aujourd'hui. Le Recrutement et la Formation des Magistrats de l'Ordre Judiciaire. Paris, Gazette du Palais.

BECKER, Howard. (1963), Outsiders. Studies in the Sociology of Deviance. New York, The Free Press.

BERGER, Peter; LUCKMANN, Thomas. (1996), The Social Construction of Reality: A Treatise in the Sociology of Knowledge. New York, Anchor Books.

BERNARD, Jessie. (1954), "The Theory of Games of Strategy as a Modern Sociology of Conflict". American Journal of Sociology, vol. 59, no 1, pp. 411-424.

BILLAND, Émilie. (2008), Concours Territoriaux et Institutionnalisation de l'Emploi Public Local (Années 1970-Années 2000). Tese (Doutorado em Sociologia), École des Hautes Études en Sciences Sociales, Paris.

. (2010), "Les Ambiguïtés de la Sélection par Concours dans la Fonction Publique Territoriale: Une Institutionnalisation Inachevée". Revue Sociologie du Travail, vol. 52, no 1, pp. 172-194.

BLUMER, Herbert. (1969), Symbolic Interactionism. Perspective and Method. Berkeley, University of California Press.

BOURDIEU, Pierre. (1989), La Noblesse d'État. Grandes Écoles et Esprit de Corps. Paris, Minuit.

; PASSERON, Jean-Claude. (1964), Les Héritiers: Les Étudiants et la Culture. Paris, Minuit.

. (1970), La Reproduction: Éléments pour une Théorie du Système d'Enseignement. Paris, Minuit.

BULMER, Martin. (1984), The Chicago School of Sociology. Chicago, University of Chicago Press.

BURGESS, Ernest W. (1929), "Basic Social Data", in T. Smith e L. White (orgs.), Chicago: An Experiment in Social Science Research. Chicago, University of Chicago Press.

CHAMPY, Florent. (2012), La Sociologie des Professions. Paris, PUF.

CICOUREL, Aaron. (1995), The Social Organization of Juvenile Justice. London, Transaction Publishers.

; KITSUSE, John. (1963), The Educational Decision-Makers. Indianapolis, Bobbs-Merrill.

COULON, Alain. (1992), L'École de Chicago. Paris, PUF.

. (1993), Ethnométhodologie et Éducation. Paris, PUF.

(1994), “Garfinkel”, in K. Van Meter (org.), La Sociologie. Paris, Larousse. 
DUPRET, Baudouin. (2001), “L'Intention en Acte. Approche Pragmatique de la Qualification Pénale dans un Contexte Égyptien”. Droit \& Société, vol. 48, no1, pp. 439-465.

DURET, Pascal. (2009), Sociologie de la Compétition. Paris, Armand Colin.

DURKHEIM, Émile. (1924), Sociologie et Philosophie. Paris, Librairie Félix Alcan. (1960), Les Formes Élémentaires de la Vie Religieuse. Paris, PUF.

EBER, Nicolas. (2004), Théorie des Jeux. Paris, Dunod.

FILLON, Catherine; BONICHI, Marc; LECOMPTE, Arnaud. (2008), Devenir Juge. Modes de Recrutement et Crise des Vocations de 1830 à nos Jours. Paris, PUF.

FILLOUX, Jean-Claude. (1994), “Coulon (Alain), Ethnométhodologie et Éducation”. Revue Française de Pédagogie, vol. 107, pp. 141-144.

FONTAINHA, Fernando de Castro. (2009), “Work Division, Domination and Solidarity in French Law Field: Scholars, Judges, and the National Judicial School's Public Contest Oral Exam", in M. Serafimova; S. Hunt; M. Marinov (orgs.), Sociology and Law: The 150th Anniversary of Emile Durkheim (1858-1917). Newcastle upon Tyne, UK, Cambridge Scholars Publishing.

(2010), “The French Judicial Public Competitive Examination, the Candidates and their Files: Construction and Self-construction in Non-face-to-face Interaction". New Cultural Frontiers, vol. 1, no 1, pp. 117-138.

. (2011), Les (en)Jeux du Concours: Une Analyse Interactionniste du Recrutement à l'École Nationale de la Magistrature. Sarrebruck, Éditions Universitaires Europeénnes.

. (2013a), “La Dimension Stratégique de l'Enseignement Juridique: L'Ethnographie d'un Debriefing". Droit et Cultures, vol. 63, pp. 165-192.

. (2013b), “Un Chercheur à l’École de la Magistrature de Rio: La Négociation d'une Posture d'Enquête dans un Monde Institutionnalisé", in G. Leturcq; F. Louault; T. C. S. Marques (orgs.), Le Brésil: Un Laboratoire pour les Sciences Sociales. Paris, l'Harmattan, pp. 135-150.

. (2014), “Como se Faz um Juiz na França? Uma Revisão de Literatura”. Confluências. Revista Interdisciplinar de Sociologia e Direito, vol. 16, no 2, pp. 134-171.

GAÏTI, Brigitte; SAWIKI, Frédéric. (1997), “On ne Subit pas son Rôle. Entretien avec Jacques Lagroye". Politix, vol. 10, no 38, pp. 7-17.

GARFINKEL, Harold. (1963), “A Conception of and Experiments with 'Trust' as a Condition of Stable Concerted Actions", in O. J. Harvey (org.), Motivation and Social Interaction. New York, The Ronald Press.

. (1967), Studies in Ethnomethodology. Cambridge, Polity Press.

; SACKS, Harvey. (1970), "On Formal Structures of Practical Actions", in J. C. McKinney e E. A. Tiryakian (org.), Theoretical Sociology: Perspectives and Developments. New York, Appleton-Century-Crofts.

GOFFMAN, Erving. (1952), "On Cooling the Mark Out. Some Aspects of Adaptation to Failure". Journal of Interpersonal Relations, vol. 15, no 4, pp. 451-463.

. (1959), The Presentation of Self in Everyday Life. New York, Anchor Books.

DADOS - Revista de Ciências Sociais, Rio de Janeiro, vol. 58, nº 4, 2015 


\section{Fernando de Castro Fontainha}

. (1961), Encounters. Two Studies in the Sociology of Interaction. New York, BobbsMerryl.

. (1961a), Asylum. Essays on the Situation of Mental Patients and other Inmates. New York, Anchor Books.

(1963), Stigma. Notes on the Management of Spoiled Identity. New York, Simon \& Schuster.

. (1967), Interaction Ritual. Essays on Face-to-face Behavior. New York, Pantheon Books.

(1969), Strategic Interaction. Filadélfia, University of Pennsylvania Press.

. (1974), Frame Analysis: An Essay on the Organization of Experience. New York, Harper Colophon Books.

HERITAGE, John. (1984), Garfinkel and Ethnomethodology. Cambridge, Polity Press.

JOSEPH, Isaac. (2000), Erving Goffman e a Microssociologia. Rio de Janeiro, Editora FGV.

LUCE, Duncan; RAIFFA, Howard. (1957), Games and Decisions. Introduction and Critical Survey. New York, John Wiley and Sons.

. (1974), Frame Analysis: An Essay on the Organization of Experience. New York, Harper Colophon Books.

MEHAN, Hugh. (1978), "Structuring School Structure". Harvard Educational Review, vol. 48 , no 1, pp. 32-64.

. (1979), “The Competent Student". Sociolinguistic Working Paper 61. Austin, Southwest Educational Development Laboratory.

MIAILLE, Michel. (2005), “Les Prédispositions à l’Esprit de Corps: Les Candidats au Concours de la Magistrature", in G. Guglielmi; C. Haroche (orgs.), Esprit de Corps: Démocratie et Espace Public. Paris, PUF, pp. 227-275.

OGER, Claire. (2002), Candidats-Modèles, Cultures et Méthodes: L'Épreuve de Culture Générale dans Trois Concours de Sélection des Élites de la Fonction Publique (École de Guerre/Cours Supérieur d'État-Major, École Nationale d'Administration, École Nationale de la Magistrature). Analyse de discours des rapports de jurys. Tese (Doutorado, Ciências da Linguagem), Université de Paris XII, Paris.

PARK, Robert; BURGESS, Ernest. (1921), Introduction to the Science of Sociology. Chicago, University of Chicago Press.

PARNELL, Philip. (2002), "Trekking Processual Planes beyond the Rule of Law", in J. Starr; M. Goodale (orgs.), Practicing Ethnography in Law. New Dialogues, Enduring Methods. New York, Palgrave Macmillan.

SHUBIK, Martin. (1982), Game Theory in the Social Sciences. Concepts and Solutions. Cambridge, The Massachusetts Institute of Technology Press.

SIMMEL, Georg. (1950), The Sociology of Georg Simmel. Glencoe, Free Press.

SWEDBERG, Richard. (2001), "Sociology and Game Theory. Contemporary and Historical Perspectives". Theory and Society, vol. 1, no 30, pp. 301-335.

THOMAS, William; ZNANIECKI, Florian. (1920), The Polish Peasant in Europe and America. Chicago, The University of Chicago Press.

VAN HAECHT, Anne. (2006), L'École à l'Épreuve de la Sociologie. La Sociologie de l'Éducation et ses Évolutions. Bruxelas, De Boek. 


\section{RESUMO}

Interação Estratégica e Concursos Públicos: Uma Etnografia do Concurso da Magistratura Francesa

Este artigo propõe um quadro analítico para os concursos públicos a partir da sociologia interacionista, sobretudo dos trabalhos do sociólogo Erving Goffman. Num primeiro momento, mostra-se como o construtivismo avançou em direção à compreensão dos processos de competição de atores, notadamente as competições escolares. Em seguida, analisa-se a recepção da Teoria dos Jogos pela Sociologia para avançar, posteriormente, no olhar goffmaniano sobre as dinâmicas interacionais: começando pelas interações cotidianas (metáfora do teatro), passando pelas interações focalizadas e desembocando nas interações estratégicas (metáfora do jogo). Por fim, uma etnografia da prova oral de cultura geral da magistratura francesa permite que as categorias teóricas trabalhadas sejam aplicadas através da descrição densa de quadros interacionais.

Palavras-chave: sociologia das profissões jurídicas; concursos públicos; rito interacional; interação estratégica; magistratura francesa

\section{ABSTRACT \\ Strategic Interaction and Public Examinations: An Ethnography of the French Magistrate Selection Process}

This article proposes and analytical framework for public examination building upon a interactionist sociology, and mainly the works of sociologist Erving Goffman. Firstly, constructivism's advance toward an understanding of processes of competition among actors is shown, with special emphasis on school competitions. Next, the reception of Game Theory by Sociology is analyzed so that the Goffmanian view of interactionist dynamics can be furthered: beginning with daily interactions (the theater metaphor), followed by focalized interactions and ending with strategic interactions (the game metaphor). Lastly, an ethnography of oral examinations assessing general culture of the French magistrate makes it possible to apply the theoretical categories through the dense descriptions of interactional frames.

Keywords: sociology of juridical professions; public examinations; interactional rites; strategic interaction; French magistrate 


\section{RÉSUMÉ}

Interaction Stratégique et Concours Publics: Une Ethnographie du Concours de la Magistrature Française

Cet article propose un cadre analytique des concours publics se basant sur la sociologie interactionniste, et plus spécifiquement sur les travaux du sociologue Erving Goffman. Dans un premier temps, nous montrerons comment le constructivisme a avancé dans sa compréhension des processus de compétition entre les acteurs, notamment dans le cadre scolaire. Nous analyserons ensuite la réception de la Théorie des jeux par la sociologie avant de nous pencher sur le regard que portait Goffman sur les dynamiques interactionnelles, en commençant par les interactions quotidiennes (métaphore du théâtre) pour finir avec les interactions stratégiques (métaphore du jeu), en passant par les interactions focalisées. Une ethnographie de l'épreuve orale de culture générale de la magistrature française nous permettra enfin de mettre en pratique les théories présentées à travers une description dense de ce cadre interactionnel.

Mots-clés: sociologie des professions juridiques; concours publics; rite interactionnel; interaction stratégique; magistrature française

\section{RESUMEN}

Interacción Estratégica y Concursos Públicos: Una Etnografía del Concurso de la Magistratura Francesa

Este artículo propone un marco analítico para estudiar los concursos públicos a partir de la sociología interaccionista, principalmente a través de los trabajos de Erving Goffman. En un primer momento, se discute el avanzo del constructivismo rumbo a la comprensión de los procesos de competición de actores, sobre todo las competiciones escolares. A seguir, se analiza la recepción de la teoría de los juegos por la sociología para examinar la mirada goffmaniana sobre las dinámicas interactivas: empezando por las interacciones cotidianas (metáfora del teatro), pasando por las interacciones focalizadas hasta llegar a las interacciones estratégicas (metáfora del juego). Finalmente, una etnografía de la prueba oral de cultura general de la magistratura francesa permite que las categorías teóricas trabajadas sean aplicadas a través de una descripción densa de cuadros interactivos.

Palabras clave: sociología de las profesiones jurídicas; concursos públicos; rito interactivo; interacción estratégica; magistratura francesa 